\title{
Treatment of systemic lupus erythematosus
} patients with the BAFF antagonist "peptibody" blisibimod (AMG 623/A-623): results from randomized, double-blind phase $1 \mathrm{a}$ and phase $1 \mathrm{~b}$ trials

William Stohl ${ }^{1,9^{*}}$, Joan T. Merrill2, R. John Looney ${ }^{3}$, Jill Buyon ${ }^{4}$, Daniel J. Wallace ${ }^{5}$, Michael H. Weisman ${ }^{5}$, Ellen M. Ginzler ${ }^{6}$, Blaire Cooke ${ }^{7}$, Donna Holloway ${ }^{8}$, Arunan Kaliyaperumal ${ }^{7}$, Kameswara Rao Kuchimanchi ${ }^{8}$, Tsui Chern Cheah, Erik Rasmussen ${ }^{7}$, John Ferbas' ${ }^{7}$, Shelley S. Belouski ${ }^{8}$, Wayne Tsuji ${ }^{7}$ and Debra J. Zack ${ }^{8}$

\begin{abstract}
Introduction: Blisibimod is a potent B cell-activating factor (BAFF) antagonist that binds to both cell membraneexpressed and soluble BAFF. The goal of these first-in-human studies was to characterize the safety, tolerability, and pharmacokinetic and pharmacodynamic profiles of blisibimod in subjects with systemic lupus erythematosus (SLE).

Methods: SLE subjects with mild disease that was stable/inactive at baseline received either a single dose of blisibimod $(0.1,0.3,1$, or $3 \mathrm{mg} / \mathrm{kg}$ subcutaneous [SC] or 1,3 , or $6 \mathrm{mg} / \mathrm{kg}$ intravenous [IV]) or placebo (phase 1a; $\mathrm{N}=54$ ), or four weekly doses of blisibimod $(0.3,1$, or $3 \mathrm{mg} / \mathrm{kg} \mathrm{SC}$ or $6 \mathrm{mg} / \mathrm{kg}$ IV) or placebo (phase $1 \mathrm{~b}$; $N=63$ ). Safety and tolerability measures were collected, and B cell subset measurements and pharmacokinetic analyses were performed.

Results: All subjects (93\% female; mean age 43.7 years) carried the diagnosis of SLE for $\geq 1$ year. Single- and multiple-dose treatment with blisibimod produced a decrease in the number of naïve B cells (24-76\%) and a transient relative increase in the memory $B$ cell compartment, with the greatest effect on IgD $C D 27+$; there were no notable changes in T cells or natural killer cells. With time, memory B cells reverted to baseline, leading to a calculated $30 \%$ reduction in total B cells by approximately 160 days after the first dose. In both the single- and multiple-dosing SC cohorts, the pharmacokinetic profile indicated slow absorption, dose-proportional exposure from 0.3 through $3.0 \mathrm{mg} / \mathrm{kg} \mathrm{SC}$ and 1 through $6 \mathrm{mg} / \mathrm{kg} \mathrm{IV}$, linear pharmacokinetics across the dose range of $1.0-6.0 \mathrm{mg} / \mathrm{kg}$, and accumulation ratios ranging from 2.21 to 2.76 . The relative increase in memory B cells was not associated with safety signals, and the incidence of adverse events, anti-blisibimod antibodies, and clinical laboratory abnormalities were comparable between blisibimod- and placebo-treated subjects.

Conclusions: Blisibimod changed the constituency of the B cell pool and single and multiple doses of blisibimod exhibited approximate dose-proportional pharmacokinetics across the dose range $1.0-6.0 \mathrm{mg} / \mathrm{kg}$. The safety and tolerability profile of blisibimod in SLE was comparable with that of placebo. These findings support further studies of blisibimod in SLE and other B cell-mediated diseases.
\end{abstract}

Trial registration: Clinicaltrials.gov NCT02443506. Registered 11 May 2015. NCT02411136 Registered 7 April 2015.

\footnotetext{
* Correspondence: stohl@usc.edu

${ }^{1}$ Los Angeles County and University of Southern California Medical Center and University of Southern California Keck School of Medicine, 1975 Zonal Ave., Los Angeles, CA 90033, USA

${ }^{9}$ Division of Rheumatology, Los Angeles County + University of Southern California Medical Center and Keck School of Medicine of the University of Southern California, 2011 Zonal Ave., Los Angeles, CA 90033, USA Full list of author information is available at the end of the article
} 


\section{Introduction}

Systemic lupus erythematosus (SLE) has a heterogeneous clinical and immunologic presentation, with the commonality of $B$ cell hyperactivity across the patient population. B cell-activating factor (BAFF, also known as B lymphocyte stimulator $[\mathrm{BLyS}]$ ) is crucial to the survival and differentiation of $B$ cells [1-5]. In animal models of SLE, BAFF overexpression promotes features of SLE [6-10] and BAFF antagonists attenuate disease progression $[8,11-13]$. In humans with SLE, circulating BAFF levels are increased in as many as $50 \%$ of patients [14-16] and numerous studies have found a positive correlation between BAFF expression and disease activity [17-21].

Given its likely contributory role to the maintenance of SLE disease activity, BAFF is an appealing target in the treatment of SLE. Two phase 3 clinical trials of the antisoluble BAFF monoclonal antibody belimumab added to standard-of-care treatment demonstrated significant effects on disease activity [22, 23]. The "peptibody" blisibimod (A-623, AMG 623) is also a BAFF antagonist, but unlike belimumab, it binds to both membrane-bound and soluble BAFF. Blisibimod inhibits the interaction of BAFF with any of its three receptors (half-maximal inhibitory concentration $\left[\mathrm{IC}_{50}\right]=0.2 \mathrm{nM}$ at $1 \mathrm{nM}$ BAFF), inhibits the in vitro BAFF-driven increases in B cell proliferation $\left(\mathrm{IC}_{50}=0.1 \mathrm{nM}\right.$ at $0.2 \mathrm{nM}$ BAFF), reduces in vivo peripheral $B$ cell numbers in nonautoimmune-prone mice, and delays the onset of proteinuria in SLE-prone (NZBxNZW)F1 mice [24]. Neutralization of both soluble and membrane-expressed BAFF by blisibimod may produce an immunologic change different from that upon neutralization of soluble BAFF alone.

We present the safety, tolerability, and pharmacokinetic and pharmacodynamic profiles of blisibimod in subjects with SLE in two multicenter, double-blind, placebo-controlled trials: a single-dose phase 1a first-inhuman study and a multiple-dose phase $1 \mathrm{~b}$ study.

\section{Methods}

\section{General}

The studies were conducted at 12 sites in the United States. The protocols were approved by each center's institutional review board (IRB) (please see the Acknowledgements), and all subjects provided written informed consent. The studies were developed and sponsored by Amgen, Inc., and blisibimod is now licensed to Anthera Pharmaceuticals, Inc. (Hayward, CA, USA).

\section{Subjects}

Men and women 18-65 years of age with mild disease that was either stable or inactive (as assessed by the investigator) were eligible for enrollment if they had a diagnosis of SLE for at least 1 year, and met the updated American College of Rheumatology classification criteria $[25,26]$. Subjects were excluded if they did not have a current or previous positive antinuclear antibody test; had active vasculitis, central nervous system lupus, acute renal disease, a glomerular filtration rate $<60 \mathrm{~mL} / \mathrm{min}$, uncontrolled hypertension or diabetes, or active infection within the previous 30 days; or had antibodies to human immunodeficiency virus, hepatitis B surface antigen, or hepatitis $\mathrm{C}$. Those who were pregnant or nursing were also excluded, as were those who had either received monoclonal antibody therapy as an investigational drug within the previous year or participated in other investigational drug or device trials within 30 days. Subjects who had received cyclosporine, tacrolimus, sirolimus, cyclophosphamide, other alkylating agents, or the equivalent of $>100 \mathrm{mg} /$ day of prednisone (pulse therapy) within 60 days or rituximab within 12 months were also not eligible. However, subjects were allowed to be treated with other SLE medications, including $\leq 10 \mathrm{mg} /$ day of prednisone or its equivalent. Other than the proscribed medications above, investigators were permitted to prescribe concomitant medications or treatments as clinically warranted. Subjects had to be willing to practice effective methods of contraception.

\section{Study design}

In the first-in-human phase 1a ascending single-dose study, subjects were sequentially enrolled into one of seven dose cohorts: $0.1,0.3,1.0$, or $3.0 \mathrm{mg} / \mathrm{kg}$ subcutaneous (SC) or 1.0, 3.0, or $6.0 \mathrm{mg} / \mathrm{kg}$ intravenous (IV) blisibimod. The $0.1 \mathrm{mg} / \mathrm{kg}$ dose was chosen as the starting dose on the basis of multiple-dosing preclinical toxicology findings in cynomolgus monkeys; the remaining doses were based on preclinical pharmacokinetic modeling and toxicology studies that showed no adverse effects (AEs) at weekly doses up to $150 \mathrm{mg} / \mathrm{kg}$ IV or SC [data on file]. Within each dose cohort, subjects were randomized (3:1 ratio) to receive blisibimod or placebo, and were followed for $28(0.1$ and $0.3 \mathrm{mg} / \mathrm{kg})$ or 42 days $(1.0,3.0$, and $6.0 \mathrm{mg} / \mathrm{kg})$ post-dose, and those in the highest dose cohort $(6.0 \mathrm{mg} / \mathrm{kg})$ completed a 4-week extension follow-up visit after their end-of-study visit. In the phase $1 \mathrm{~b}$ ascending multiple-dose study, subjects were sequentially enrolled into one of four dose cohorts: $0.3,1.0$, or $3.0 \mathrm{mg} / \mathrm{kg} \mathrm{SC}$ or $6.0 \mathrm{mg} / \mathrm{kg} \mathrm{IV}$. Within each dose cohort, subjects were randomized (4:1 ratio) to receive four weekly doses of blisibimod or placebo, and the pharmacokinetics of blisibimod were followed to day $63(0.3$ and $1.0 \mathrm{mg} / \mathrm{kg})$ or day $112(3.0$ and $6.0 \mathrm{mg} / \mathrm{kg})$. For both studies, blisibimod was given as a $30 \mathrm{mg} / \mathrm{mL}$ formulation in vehicle. Those assigned to the placebo group received an equivalent volume of the corresponding vehicle. 


\section{End points}

The primary end point of both studies was the characterization of the safety and tolerability of blisibimod. Safety and tolerability assessments included the incidence of treatment-emergent AEs, and clinically significant changes in vital signs, electrocardiograms (ECGs), and clinical laboratory safety tests. AEs were classified using Medical Dictionary for Regulatory Activities (MedDRA) terminology, and clinical laboratory results were assessed using the grading criteria of the National Institute of Health Common Toxicity Criteria for Adverse Events (NIH CTCAE). Secondary end points were the pharmacokinetic and pharmacodynamic profiles of blisibimod following single or multiple SC or IV doses. Exploratory end points included changes in peripheral blood B cell counts and expression of B cell surface markers.

\section{Pharmacokinetic analysis}

Serum concentrations of blisibimod were assessed at each visit beginning on day 1 (the day before dosing) and continuing through the end of the studies, with extensive serum collections after the first and fourth doses (phase $1 \mathrm{~b}$ study only). Pharmacokinetic parameters were derived for each subject from the blisibimod serum concentrations: these parameters included area under the plasma-concentration curve from time of treatment to the last measurable concentration $\left(\mathrm{AUC}_{0-\mathrm{t}}\right)$, maximum observed serum concentration $\left(\mathrm{C}_{\max }\right)$, estimated initial concentration after IV bolus dosing $\left(C_{0}\right)$, time to $C_{\max }\left(t_{\max }\right)$, half-life $\left(t_{1 / 2, z}\right)$, clearance $(C L)$, apparent clearance after SC dosing $(\mathrm{CL} / \mathrm{F})$, and accumulation ratio (AR). Blisibimod concentrations over time, as well as pharmacokinetic parameter values were summarized by route and dose.

\section{Immunogenicity analysis}

The presence of neutralizing serologic reactivity to blisibimod was analyzed using two validated assays at screening in both studies, at the end of the phase 1a study, and on day 29 in the phase $1 \mathrm{~b}$ study. The first was a Biacore immunoassay to establish the presence of binding antibodies, and the second was an in vitro cellbased bioassay to detect neutralizing or inhibitory effects toward blisibimod in pre- and post-dose samples. All samples that tested positive in the immunoassay were tested in the bioassay along with their corresponding pre-dose samples, even if the pre-dose samples did not test positive in the immunoassay. If a sample was positive in both the Biacore assay and the cell-based assay, the subject was defined as positive for neutralizing antibodies.

\section{Exploratory B cell analysis}

In the phase 1a study, whole blood specimens were collected at screening visit day 1 , pre-dose on the day of dosing, post-dose on days 14 and 28 for all dose groups, day 42 for the 3.0 and $6.0 \mathrm{mg} / \mathrm{kg}$ dose groups, and at the extension/follow-up for all dose groups. In the phase $1 \mathrm{~b}$ study, whole blood specimens were collected twice before study inclusion (at screening day 28, re-screen); pre-dose on day 1 ; post-dose on days $15,29,50,64,78$, $110,134,164,190,218$; and early termination (when applicable). Whole blood specimens were shipped at ambient temperature to ICON Central Laboratories within the previously established 48-hour stability time frame for standard hematology assessment and flow cytometry determinations [data on file]. A standard clinical hematology analyzer was used to enumerate total lymphocyte counts. Detailed methods are provided elsewhere [27].

Antibody combinations were chosen to permit enumeration of total $\mathrm{B}$ cells $\left(\mathrm{CD} 19^{+} \mathrm{CD} 20^{+}\right)$, naïve $\mathrm{B}$ cells $\left(\mathrm{CD} 19^{+} \operatorname{sIgD}^{+} \mathrm{CD} 27^{-}\right), \mathrm{IgD}^{+}$memory B cells $\left(\mathrm{CD} 19^{+} \mathrm{sIgD}\right.$

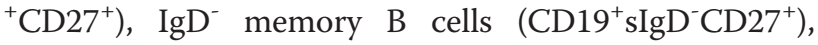
total $\mathrm{T}$ cells $\left(\mathrm{CD}^{+}{ }^{+} \mathrm{CD} 16 / \mathrm{CD}^{-} 6^{-}\right)$, and natural killer cells $\left(\mathrm{CD} 3^{-} \mathrm{CD} 16 / \mathrm{CD}^{+} 6^{+}\right)$. Plasmablasts were previously assessed and determined not to be sufficiently stable for assessment in the phase 1 studies [27]; although they were analyzed in the phase 1a study, the data were not used because of cell instability. The antibody configurations and clone numbers were as follows: Tube 1: CD20 FITC (L27), CD45 APC (2D1), CD19 PerCP (SJ25C1); Tube 2: CD3 FITC (SK7), CD16 PE (B73.1), CD56 PE (MY31), CD45 APC (2D1); Tube 3: CD27 FITC (L128), CD38 PE (HB7), CD19 PerCP (SJ25C1), CD45 APC (2D1); Tube 4: CD27 FITC (L128), IgD PE (IA6-2), CD19 PerCP (SJ25C1), CD45 APC (2D1), Tube 5: CD138 FITC (MI15), CD38 PE (HB7), CD19 PerCP (SJ25C1), CD45 APC (2D1). The entire panel was performed in the phase 1a study; in the phase $1 \mathrm{~b}$ study, the routine panel (tubes $1-3$ ) was performed at screening visit day 28 , re-screen, and days 64 , 110, 134, 164, and 190. The extended panel (all tubes) was performed on phase $1 \mathrm{~b}$ specimens drawn on days $1,15,29$, $50,78,218$, and early termination. Monitoring was not required if the change in B cell level was $\leq 20 \%$, or levels had returned to either within $20 \%$ of baseline or a level from a reference range of healthy volunteers, whichever was lower; subjects could be released from monitoring as early as day 190 . Those that did not meet these criteria were asked to return monthly until the criteria were met or they were released by medical board review.

\section{Statistical analyses}

Demographic, safety, pharmacokinetic, and B cell data for each route and dose were analyzed with descriptive statistics. After review, data were combined for the placebo groups by any route. The primary safety analysis was performed for all subjects who received an investigational product (blisibimod or placebo). 
The relationship between blisibimod dose and changes in lymphocyte phenotypes was explored graphically using a cubic spline [28] to visualize potential trends over time by dose and route. After reviewing these graphs, exploratory modeling of the relationship between dose/route and select lymphocyte phenotypes was analyzed using a mixed-effects model, with baseline value and actual treatment as fixed effects, and subject as a random effect. Based on graphical review, post-dose times were grouped as dosing (days 15-42), post-dosing (days 43-100), and extended follow-up (> day 100) phases, with exploratory modeling performed separately for these three post-dose time ranges. Because they were similar, blisibimod $1.0 \mathrm{mg} / \mathrm{kg}$ and $3.0 \mathrm{mg} / \mathrm{kg}$ dose groups were pooled and compared with the placebo group for each post-dose phase using an $\mathrm{F}$ test $(P$ values reported for these comparisons should be considered descriptive). Reference ranges of the mean, standard error, and coefficient of reliability of healthy volunteer and SLE subsets were established in a previously published study [27].

\section{Results}

\section{Subject disposition and baseline characteristics}

In the phase 1a study, 56 subjects were enrolled and randomized; 54 were dosed. Two subjects (blisibimod, $\mathrm{n}=1$; placebo, $\mathrm{n}=1$ ) did not receive the study drug due to study ineligibility: the subject in the blisibimod group developed an infection before dosing, and the subject in the placebo group had a glomerular filtration rate $<60 \mathrm{~mL} / \mathrm{min}$. Only one subject (placebo) was withdrawn from the phase 1a study due to a serious adverse event (SAE; see Safety and tolerability). In the phase $1 \mathrm{~b}$ study, 64 subjects were enrolled and randomized; 63 were dosed. One blisibimod-assigned subject did not receive the study drug due to study ineligibility (papillary lesion requiring an excision), and one placebo-assigned subject who received blisibimod instead of placebo at the fourth dose was excluded from the analyses. Four subjects (blisibimod, $\mathrm{n}=2$; placebo, $n=2$ ) withdrew from the study due to an AE: in the blisibimod cohort, AEs were migraine and hypersensitivity, and in the placebo cohort, AEs were cellulitis and abscessed limb. One additional subject from the placebo group withdrew from the study at the subject's request.

Demographics and baseline disease characteristics were similar between the treatment groups, with the exception of CD19 antigen median fluorescence intensity (MFI), which was statistically significantly higher in the blisibimod versus placebo group (Tables 1, 2). Concomitant medication use was high, with a large portion of subjects taking prednisone (39-45\%) and hydroxychloroquine (38-63\%).

\section{Blisibimod pharmacokinetics}

After single and four weekly IV injections, blisibimod serum concentration-time profiles were biphasic: there was an initial distribution phase followed by a slower elimination phase (Fig. 1a, c). Based on $\mathrm{C}_{0}$ and AUC, exposure increased in an approximate dose-proportional manner from 1.0 to $6.0 \mathrm{mg} / \mathrm{kg}$ IV (Tables 3, 4). In the single-dose cohorts, the mean $t_{1 / 2, \mathrm{z}}$ for the $6.0 \mathrm{mg} / \mathrm{kg} \mathrm{IV}$ dose group was 8.7 days (Table 3 ); in the multiple-dose cohort for the $6.0 \mathrm{mg} / \mathrm{kg}$ IV dose group, 12 days (Table 4). The mean CL ranged from 47.5 to $51.9 \mathrm{~mL} / \mathrm{hr}$ after a single IV dose (Table 3 ) and $34 \mathrm{~mL} /$ hour after multiple IV doses (Table 4). These similar CL values indicate linear pharmacokinetics across a sixfold range of 1.0 to $6.0 \mathrm{mg} / \mathrm{kg}$. Blisibimod exhibited a 2.3-fold AR after the fourth dose compared with the first dose (Table 4).

After single and four weekly SC injections, the median $\mathrm{t}_{\max }$ ranged from 47 to 49 hours post-dose, indicating slow absorption with SC dosing (Tables 3, 4; Fig. 1b, c). Based on AUC and $C_{\max }$, exposure to blisibimod increased in an approximate dose-proportional manner from 0.3 to $3.0 \mathrm{mg} / \mathrm{kg} \mathrm{SC}$ (Table 3). After a single dose, the mean $t_{1 / 2, z}$ over this tenfold dose range was 8.5 days (Table 3); after the fourth weekly dose, 9.3 days (Table 4). The mean apparent CL/F was $85.1 \mathrm{~mL} / \mathrm{hr}$ after a single dose and $72.9 \mathrm{~mL} / \mathrm{hr}$ after multiple doses. Following four weekly doses of blisibimod, moderate accumulation was seen, with ratios ranging from 2.2 to 2.8 (Table 4).

\section{Anti-blisibimod antibodies}

In the phase 1a study, 19 of the 40 (48\%) blisibimodand four of the 13 (31\%) placebo-treated subjects were positive for anti-blisibimod binding antibodies at any time; none of these antibodies were neutralizing. In the phase 1b study, 19 of the 49 (39\%) blisibimod- and seven of the 14 (50\%) placebo-treated subjects were positive for anti-blisibimod binding antibodies at any time point; three (6\%) blisibimod-treated subjects were positive for neutralizing antibodies in this study. All subjects were negative for neutralizing antibodies at followup visits at the end of the study.

\section{Changes in lymphocyte populations following treatment with blisibimod}

Baseline flow cytometry variables measured in this study were generally similar between the blisibimod and placebo groups (Table 5; Fig. $2 \mathrm{a}-\mathrm{d}$ ). Total lymphocytes, T cells, and natural killer cells did not exhibit significant changes relative to baseline. Three changes were observed with blisibimod: first, a reduction of total B cells (Fig. 2a, $\geq$ day 75; Table 5, day $>100, P=0.006$ ). Second, disproportionate changes occurred within the subsets of $B$ cells that remained in the blood post-treatment: there 
Table 1 Demographics and disease characteristics of patients with systemic lupus erythematosus in the phase 1a study

\begin{tabular}{|c|c|c|c|c|c|c|c|c|c|}
\hline \multirow[b]{3}{*}{ Baseline characteristics } & \multirow{3}{*}{$\begin{array}{l}\text { Placebo } \\
(n=14)\end{array}$} & \multicolumn{8}{|l|}{ Blisibimod } \\
\hline & & \multicolumn{4}{|l|}{$\mathrm{mg} / \mathrm{kg} \mathrm{SC}$} & \multicolumn{3}{|l|}{$\mathrm{mg} / \mathrm{kg}$ IV } & \multirow{2}{*}{$\begin{array}{l}\text { All } \\
(\mathrm{N}=40)\end{array}$} \\
\hline & & $0.1(n=6)$ & $0.3(n=6)$ & $1.0(n=9)$ & $3.0(n=6)$ & $1.0(n=6)$ & $3.0(n=1)$ & $6.0(n=6)$ & \\
\hline \multicolumn{10}{|l|}{ Sex, n (\%) } \\
\hline Female & $13(93)$ & $5(83)$ & $6(100)$ & $8(89)$ & $6(100)$ & $6(100)$ & $1(100)$ & $6(100)$ & $38(95)$ \\
\hline Male & $1(7)$ & $1(17)$ & $0(0.0)$ & $1(11)$ & $0(0.0)$ & $0(0.0)$ & $0(0.0)$ & $0(0.0)$ & $2(5)$ \\
\hline \multicolumn{10}{|l|}{ Race, n (\%) } \\
\hline White & $2(14)$ & $2(33)$ & $1(17)$ & $1(11)$ & $0(0)$ & $2(33)$ & $1(100)$ & $3(50)$ & $10(25)$ \\
\hline Black & $5(36)$ & $5(50)$ & $3(50)$ & $1(11)$ & $2(33)$ & $1(17)$ & $0(0)$ & $2(33)$ & $12(30)$ \\
\hline Hispanic & $7(50)$ & $0(0)$ & $2(33)$ & $7(78)$ & $4(67)$ & $3(50)$ & $0(0)$ & $0(0)$ & $16(40)$ \\
\hline Asian & $0(0)$ & $0(0)$ & $0(0)$ & $0(0)$ & $0(0)$ & $0(0)$ & $0(0)$ & $1(17)$ & $1(3)$ \\
\hline Pacific Islander & $0(0)$ & $1(17)$ & $0(0)$ & $0(0)$ & $0(0)$ & $0(0)$ & $0(0)$ & $0(0)$ & $1(3)$ \\
\hline \multicolumn{10}{|l|}{ Age (years) } \\
\hline Median & 39.5 & 48.5 & 47.5 & 46.0 & 45.0 & 38.0 & 52.0 & 53.0 & 46.0 \\
\hline Range & $21-55$ & $32-53$ & $30-52$ & $31-55$ & $36-53$ & $28-55$ & - & $32-55$ & $28-55$ \\
\hline \multicolumn{10}{|l|}{ Medications, n (\%) } \\
\hline Prednisone (+ MePred) & $7(50)$ & $3(50)$ & $1(17)$ & $7(78)$ & $4(67)$ & $3(50)$ & $1(17)$ & $0(0)$ & $18(45)$ \\
\hline Hydroxychloroquine & $6(43)$ & $2(33)$ & $2(33)$ & $6(67)$ & $4(67)$ & $1(17)$ & $0(0)$ & $0(0)$ & $15(38)$ \\
\hline Azathioprine & $4(29)$ & $3(50)$ & $1(17)$ & $3(33)$ & $1(17)$ & $1(17)$ & $0(0)$ & $0(0)$ & $9(23)$ \\
\hline Mycophenolate & $4(29)$ & $0(0)$ & $2(33)$ & $3(33)$ & $1(17)$ & $0(0)$ & $1(17)$ & $0(0)$ & $7(18)$ \\
\hline Methotrexate & $1(7)$ & $0(0)$ & $0(0)$ & $1(11)$ & $0(0)$ & $2(33)$ & $0(0)$ & $0(0)$ & $3(8)$ \\
\hline Anti-dsDNA, n & 12 & 6 & 6 & 9 & 6 & 4 & 5 & 0 & 36 \\
\hline Median (range), IU/mL ${ }^{\mathrm{a}}$ & $30(30-300)$ & $179(30-300)$ & $30(30-206)$ & $30(30-300)$ & $30(30-187)$ & $30(30-294)$ & $30(30-40)$ & - & $30(30-300)$ \\
\hline C3 (IU,mL), median (range) & $114(58-168)$ & $131(76-189)$ & $132(104-188)$ & $126(95-187)$ & $123(63-154)$ & $148(95-173)$ & $113(111-120)$ & - & $125(63-189)$ \\
\hline C4 (IU,mL), median (range) & $13(5-38)$ & $17(13-40)$ & $34(12-38)$ & $22(13-44)$ & $14(9-30)$ & $33(23-40)$ & $23(18-31)$ & - & $23(9-44)$ \\
\hline
\end{tabular}

Abbreviations: C3 complement 3, C4, complement 4, dsDNA double-stranded DNA, IV intravenous, MePred methylprednisolone, SC subcutaneous

${ }^{\text {a}}$ Reference ranges are $<30 \mathrm{IU} / \mathrm{mL}$ for negative, $30-75 \mathrm{IU} / \mathrm{mL}$ for borderline, and $>75 \mathrm{UI} / \mathrm{mL}$ for positive for all age ranges

was a decrease in the proportion of $\operatorname{IgD}^{+} \mathrm{CD} 27^{-}$naïve $\mathrm{B}$ cells (Fig. 2b, $\geq$ day 45; Table 5, day 43-100, $P<0.01$ ) and an increase in the proportion of $\operatorname{IgD} \mathrm{CD}^{-} 7^{+}$memory B cells (Fig. 2d, > day 15; Table 5, day 15-42, $P=0.02$ ). Third, there was an increase in the fluorescent intensity (i.e., antigen density) of CD19 (CD19 MFI, Table $5,>$ day $100, P<0.01)$ and a decrease in the CD38 antigen on B cells (CD38 on B cells MFI, Table 5, day $15-42, P<0.01)$.

\section{Safety and tolerability}

In the phase 1a study, 28 (70\%) blisibimod- and 11 (79 \%) placebo-treated subjects reported $\geq 1 \mathrm{AE}$ (Table 6). Two SAEs were reported: one each $(8 \%$ each) in the blisibimod $3.0 \mathrm{mg} / \mathrm{kg} \mathrm{SC}$ (17\%; ureteral stones, hydronephrosis, and pyelonephritis; this subject continued in the study) and in the placebo cohorts (7 \%; pneumococcal pneumonia and bacteremia; this subject withdrew from the study). Both SAEs were considered by the investigator to be related to the study medication.
In the phase 1b study, 47 (96\%) blisibimod- and 12 (92\%) placebo-treated subjects reported $\geq 1 \mathrm{AE}$ (Table 7). Nine SAEs were reported in eight (13\%) subjects (blisibimod, $\mathrm{n}=5$ across all dose groups [10 \%]; placebo, $\mathrm{n}=3[23 \%])$. In the in the $0.3 \mathrm{mg} / \mathrm{kg}$ blisibimod SC cohort, two subjects experienced SAEs: one a polyarthritis lupus flare and the other severe depression (8\% each). In the blisibimod $1.0 \mathrm{mg} / \mathrm{kg} \mathrm{SC}$ cohort, one subject experienced chest pain, pyrexia, and a moderate increase in prothrombin time; in the $3.0 \mathrm{mg} / \mathrm{kg} \mathrm{SC}$ cohort, one subject experienced moderate syncope $(8 \%$ each). None of these SAEs were considered related to the study drug and all subjects remained in the study. In the blisibimod $6.0 \mathrm{mg} / \mathrm{kg}$ IV cohort, one $(8 \%)$ subject experienced SAEs of severe sick sinus syndrome and ECG QTc interval prolongation, which were considered by the investigator to possibly be related to the study drug; however, this subject remained in the study. In the placebo cohort, SAEs of pericarditis and pericardial effusion, mild SLE flare, and cellulitis were reported in three subjects (23\%); none were considered 
Table 2 Demographics and disease characteristics of patients with systemic lupus erythematosus in the phase $1 \mathrm{~b}$ study

\begin{tabular}{|c|c|c|c|c|c|c|}
\hline \multirow[b]{3}{*}{ Baseline characteristics } & \multirow{3}{*}{$\begin{array}{l}\text { Placebo } \\
(\mathrm{n}=13)\end{array}$} & \multicolumn{5}{|l|}{ Blisibimod } \\
\hline & & \multicolumn{3}{|l|}{$\mathrm{mg} / \mathrm{kg} \mathrm{SC}$} & \multirow{2}{*}{$\begin{array}{l}6.0 \mathrm{mg} / \mathrm{kg} \text { IV } \\
(\mathrm{n}=12)\end{array}$} & \multirow{2}{*}{$\begin{array}{l}\text { All } \\
(N=49)\end{array}$} \\
\hline & & $0.3(n=12)$ & $1.0(n=13)$ & $3.0(n=12)$ & & \\
\hline \multicolumn{7}{|l|}{ Sex, n (\%) } \\
\hline Female & $12(92)$ & $12(100)$ & $12(92)$ & $12(100)$ & $9(75)$ & $45(92)$ \\
\hline Male & $1(8)$ & $0(0)$ & $1(8)$ & $0(0)$ & $3(25)$ & $4(8)$ \\
\hline \multicolumn{7}{|l|}{ Race, n (\%) } \\
\hline White & $6(46)$ & $7(58)$ & $9(69)$ & $4(33)$ & $5(42)$ & $25(51)$ \\
\hline Black & $2(15)$ & $3(25)$ & $3(23)$ & $1(8)$ & $2(17)$ & $9(18)$ \\
\hline Hispanic & $5(38)$ & $1(8)$ & $1(8)$ & $6(50)$ & $5(42)$ & $13(27)$ \\
\hline Asian & $0(0)$ & $1(8)$ & $0(0)$ & $1(8)$ & $0(0)$ & $2(4)$ \\
\hline \multicolumn{7}{|l|}{ Pacific Islander } \\
\hline Age (years), median (range) & $45.0(22-64)$ & $41.5(21-62)$ & $47.0(34-63)$ & $44.0(24-66)$ & $44.5(26-62)$ & $43.0(21-66)$ \\
\hline SLEDAI, median (range) & $3(0-11)$ & $4(0-6)$ & $2(0-14)$ & $4(0-12)$ & $2(0-10)$ & $2(0-14)$ \\
\hline \multicolumn{7}{|l|}{ Medications, n (\%) } \\
\hline Prednisone (+ MePred) & $7(54)$ & $4(33)$ & $5(38)$ & $6(50)$ & $4(33)$ & $19(39)$ \\
\hline Hydroxychloroquine & $13(100)$ & $4(33)$ & $9(69)$ & $9(75)$ & $9(75)$ & $31(63)$ \\
\hline Azathioprine & $4(31)$ & $1(8)$ & $4(31)$ & $1(8)$ & $1(8)$ & $7(14)$ \\
\hline Mycophenolate & $2(15)$ & $2(17)$ & $1(8)$ & $1(8)$ & $0(0)$ & $4(8)$ \\
\hline Methotrexate & $0(0)$ & $1(8)$ & $0(0)$ & $1(8)$ & $1(8)$ & $3(6)$ \\
\hline Anti-dsDNA, n & 13 & 12 & 13 & 11 & 12 & 48 \\
\hline Median (range), IU/mL ${ }^{\mathrm{a}}$ & $36(30-300)$ & $30(30-300)$ & $36(11-300)$ & $30(30-300)$ & $30(30-300)$ & $30(11-300)$ \\
\hline C3 (IU/mL), median (range) & $96(47-167)$ & $131(78-179)$ & $100(65-266)$ & $107(74-160)$ & $119(82-168)$ & $119(65-266)$ \\
\hline C4 (UI/mL), median (range) & $20(9-43)$ & $19(5-58)$ & $23(7-55)$ & $21(8-46)$ & $23(5-50)$ & $21(5-58)$ \\
\hline
\end{tabular}

Abbreviations: C3 complement 3, C4 compliment 4, dsDNA double-stranded DNA, IV intravenous, MePred methylprednisolone, SC subcutaneous, SLEDAI Systemic Lupus Erythematosus Disease Activity Index

${ }^{a}$ Reference ranges are $<30 \mathrm{IU} / \mathrm{mL}$ for negative, $30-75 \mathrm{IU} / \mathrm{mL}$ for borderline, and $>75 \mathrm{Ul} / \mathrm{mL}$ for positive for all age ranges

related to the study drug and all subjects remained in the study.

One $(8 \%)$ subject in the phase $1 \mathrm{~b}$ blisibimod $3.0 \mathrm{mg} / \mathrm{kg}$ SC group had a significant change from baseline in Fridericia QTc interval; no other clinically meaningful changes in ECGs were seen. No clinically significant drug-related trends were observed in clinical laboratory data or vital signs.

\section{Discussion}

In the present studies, treatment with blisibimod produced significant changes in B cell subpopulations and B cell surface molecule density were observed, with no notable changes in $\mathrm{T}$ cells or natural killer cells. There was an initial transient increase of the B cell pool in subjects treated with single or multiple doses of blisibimod, but this was not statistically significant and was similar to previous findings in SLE patients treated with the BAFF antagonists atacicept $[29,30]$ and belimumab $[31,32]$. Blisibimod showed consistency in half-life and linearity across dose ranges for both IV and SC routes of administration, with half-life ranging from 7 to 12 days for the 0.3 to $6.0 \mathrm{mg} / \mathrm{kg}$ IV and SC dose groups, and clearance estimates constant over the 1.0 to $6.0 \mathrm{mg} / \mathrm{kg}$ IV and SC doses ranging from 34 to $79 \mathrm{~mL} / \mathrm{hr}$. The safety and tolerability of single or multiple SC or IV doses of blisibimod were comparable with those associated with placebo administration, and $\mathrm{AE}$ and treatmentrelated events did not increase with increasing doses of blisibimod.

The main finding of these studies was the statistically significant decrease in B cell counts (Table 5, > day 100, $P=0.10$ ), although the reduction was not as large as those seen during treatment with the lytic agent rituximab [33]. The constituency of the B cell pool also changed following treatment with blisibimod: there was a decrease in the number of naïve B cells (24-76 \% reduction, day 43-100) and a relative increase in the memory B cell compartment, with the greatest effect on $\operatorname{IgD}^{-} \mathrm{CD}^{2} 7^{+}(53-154 \%$ increase, day $15-42)$. One possible mechanism for these results may be related to differences in the expression profiles of BAFF 


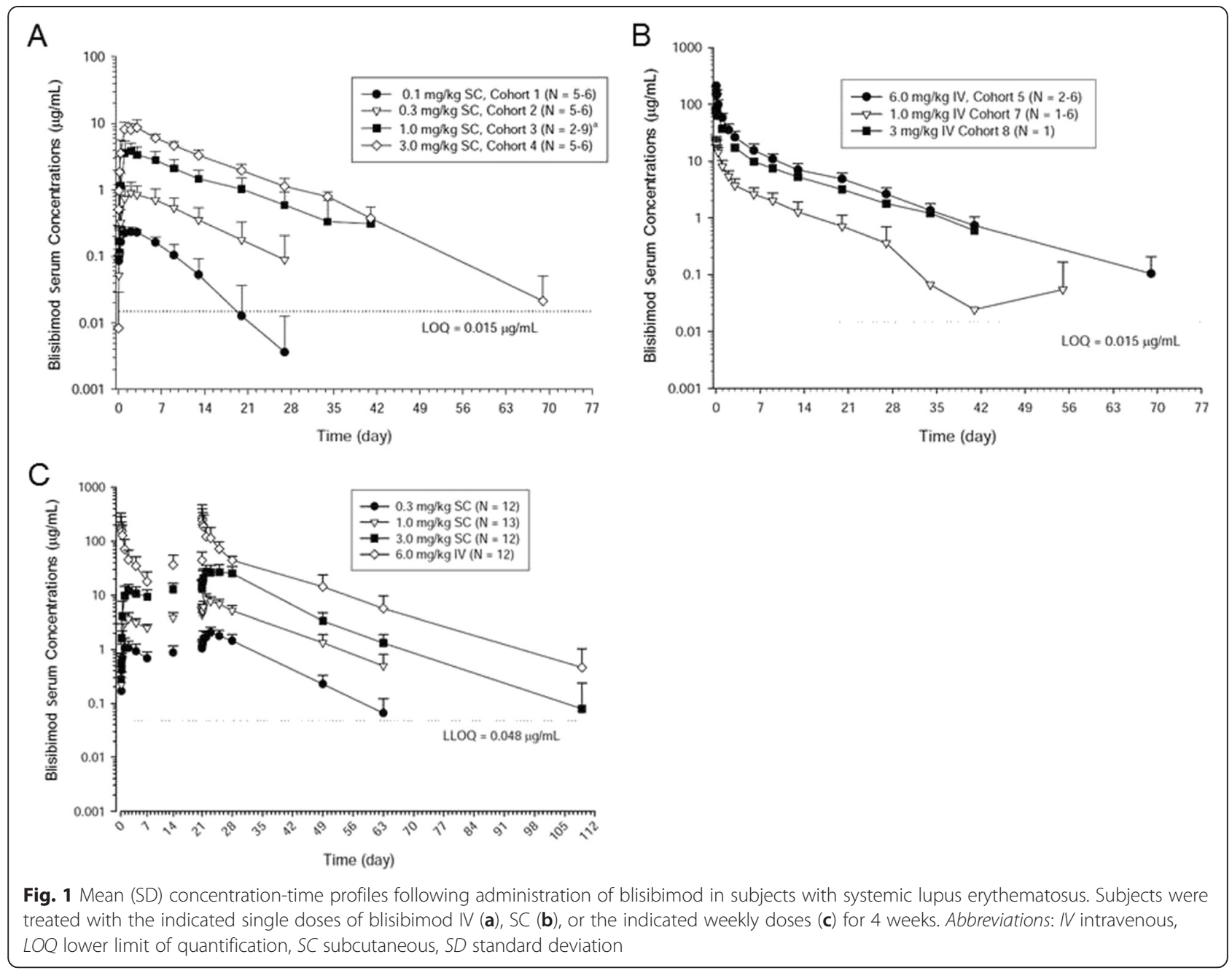

Table 3 Pharmacokinetic parameters and incidence of anti-blisibimod antibodies in patients with systemic lupus erythematosus in the phase 1a study

\begin{tabular}{|c|c|c|c|c|c|c|c|}
\hline & \multicolumn{4}{|l|}{$\mathrm{mg} / \mathrm{kg} \mathrm{SC}$} & \multicolumn{3}{|l|}{$\mathrm{mg} / \mathrm{kg}$ IV } \\
\hline & $0.1(n=6)$ & $0.3(n=6)$ & $1.0(n=9)$ & $3.0(n=6)$ & $1.0(n=6)$ & $3.0(n=1)$ & $6.0(n=6)$ \\
\hline \multicolumn{8}{|l|}{ Parameter, mean (SD) } \\
\hline $\mathrm{t}_{\max }(\mathrm{hr})$ & $48(2.2-72)$ & $48(47-70)$ & $48(24-72)$ & $47(23-73)$ & $0.61(0.083-1.1)$ & 0.083 & $0.42(0.17-0.67)$ \\
\hline$C_{\max }$ or $C_{0}(\mu \mathrm{g} / \mathrm{hr})$ & $0.273(0.0817)$ & $0.916(0.397)$ & $4.14(1.54)$ & $9.32(2.57)$ & $21.2(4.11)$ & 80.9 & 190 \\
\hline$A \cup C_{0-\mathrm{t}}\left(\mathrm{hr}{ }^{*} \mu \mathrm{g} / \mathrm{mL}\right)$ & $50.0(15.9)$ & $252(123)$ & $1140(384)$ & $2770(459)$ & $1460(543)$ & 6610 & $9440(1980)$ \\
\hline $\mathrm{t}_{1 / 2, z}($ day $)$ & $4.0(1.1)$ & $6.5(2.9)$ & $9.8(2.5)$ & $8.4(2.1)$ & $7.9(2.8)$ & 8.4 & $8.7(2.0)$ \\
\hline $\mathrm{CL} / \mathrm{F}$ or $\mathrm{CL}(\mathrm{mL} / \mathrm{hr})$ & $179(62.2)$ & $112(49.4)$ & $72.0(26.9)$ & $77.8(24.7)$ & $51.9(6.96)$ & 48.6 & $47.5(7.54)$ \\
\hline \multicolumn{8}{|l|}{ Antibodies, n (\%) } \\
\hline Pre-dose only & $0(0)$ & $3(50)$ & $0(0)$ & $0(0)$ & $1(17)$ & $0(0)$ & $0(0)$ \\
\hline Post-dose only & $4(67)$ & $1(17)$ & $3(33)$ & $1(17)$ & $0(0)$ & $1(17)$ & $0(0)$ \\
\hline Pre- and post-dose & $0(0)$ & $0(0)$ & $0(0)$ & $2(33)$ & $0(0)$ & $2(33)$ & $1(100)$ \\
\hline
\end{tabular}

Abbreviations: $A \cup C_{0-t}$ plasma-concentration curve from time of treatment to the last measurable concentration, $C_{\max }$ maximum observed serum concentration, $C_{0}$ estimated initial concentration after IV bolus dosing, $C L$ clearance $(\mathrm{CL}), \mathrm{CL} / \mathrm{F}$ apparent clearance, $I V$ intravenous, $S C$ subcutaneous, $S D$ standard deviation, $t_{1 / 2, z}$ half-life, $t_{\max }$ time to $C_{\max }$ 
Table 4 Pharmacokinetic parameters and incidence of anti-blisibimod antibodies in patients with systemic lupus erythematosus in the phase $1 \mathrm{~b}$ study

\begin{tabular}{|c|c|c|c|c|c|c|c|c|}
\hline \multirow[b]{2}{*}{ Parameter, mean (SD) } & \multicolumn{2}{|c|}{$0.3 \mathrm{mg} / \mathrm{kg} \mathrm{SC}(\mathrm{n}=12)$} & \multicolumn{2}{|c|}{$1.0 \mathrm{mg} / \mathrm{kg} \mathrm{SC}(\mathrm{n}=13)$} & \multicolumn{2}{|c|}{$3.0 \mathrm{mg} / \mathrm{kg} \mathrm{SC}(\mathrm{n}=12)$} & \multicolumn{2}{|c|}{$6.0 \mathrm{mg} / \mathrm{kg} \mathrm{IV}(\mathrm{n}=12)$} \\
\hline & Day 1 & Day 22 & Day 1 & Day 22 & Day 1 & Day 22 & Day 1 & Day 22 \\
\hline $\mathrm{t}_{\max }(\mathrm{hr})$ & 47 (24-97) & $48(24-96)$ & $49(25-170)$ & $26(8-73)$ & $47(20-170)$ & $49(0.58-170)$ & N/A & N/A \\
\hline$C_{\max }$ or $C_{0}(\mu \mathrm{g} / \mathrm{hr})$ & $1.18(0.498)$ & $2.13(0.466)$ & $3.84(1.02)$ & $8.21(1.88)$ & $13.2(4.49)$ & $34.6(8.84)$ & $243(128)$ & $315(163)$ \\
\hline$A \cup C_{0-t}\left(h r^{*} \mu g / m L\right)$ & $149(54.7)$ & $657(203)$ & $484(100)$ & $2780(862)$ & $1670(479)$ & $9450(2850)$ & $8100(3740)$ & $35600(15600)$ \\
\hline $\mathrm{t}_{1 / 2, z}$ (day) & NC & $7.9(1.3)$ & NC & $9.8(1.6)$ & NC & $10(2.4)$ & NC & $12(2.4)$ \\
\hline $\mathrm{CL} / \mathrm{F}$ or $\mathrm{CL}(\mathrm{mL} / \mathrm{hr})$ & NC & $79.7(38.2)$ & NC & $78.2(30.4)$ & $\mathrm{NC}$ & $59.9(16.3)$ & NC & $34.0(18.6)$ \\
\hline$A R$ & $2.21(0.74)$ & & $2.21(0.52)$ & & $2.76(0.89)$ & & $2.31(0.34)$ & \\
\hline \multicolumn{9}{|l|}{ Antibodies, n (\%) } \\
\hline Pre-dose only & $0(0)$ & & $1(8)$ & & $1(8)$ & & $1(8)$ & \\
\hline Post-dose only & $7(58)$ & & $1(8)$ & & $1(8)$ & & $6(50)$ & \\
\hline Pre- and post-dose & $0(0)$ & & $1(8)$ & & $1(8)$ & & $0(0)$ & \\
\hline Neutralizing & $2(17)$ & & $1(8)$ & & $0(0)$ & & $0(0)$ & \\
\hline
\end{tabular}

Abbreviations: $A R$ accumulation ratio, $A U C_{0-t}$ plasma-concentration curve from time of treatment to the last measurable concentration, $C_{\text {max }}$ maximum observed serum concentration, $C_{0}$ estimated initial concentration after IV bolus dosing, $C L$ clearance (CL), $C L / F$ apparent clearance, $I V$ intravenous, $N A$ not applicable, $N C$ not calculated, $S C$ subcutaneous, $S D$ standard deviation, $t_{1 / 2, z}$ half-life, $t_{\max }$ time to $C_{\max }$

receptors on various $B$ cell subsets, as BAFF is known to differentially support the stages of B cell development [1-5]. The relative increase in the memory B cell compartment was not associated with safety signals or elevations of immunoglobulin or anti-blisibimod antibody levels. In fact, when comparing these data with those of healthy volunteers from our previous study [27], blisibimod seemed to correct the B cell compartment to be more like that of healthy subjects, suggesting that if normalization of these cell types can be associated with clinical improvement, these may be a treatment goal in future studies.

Markers of the metabolic activity of targeted cells were also examined, as BAFF deprivation might suppress excess metabolic activity of those cells that were not depleted. The fluorescence intensity of CD19 was measured because CD19 is part of the signaling complex that modulates the threshold of activation of the $\mathrm{B}$ cell receptor, and it is known to exhibit genetic variations that correlate to expression levels and autoimmunity [34]. The changes in CD19 density were variable, with increases of $119-154 \%$ for all doses except $6.0 \mathrm{mg} / \mathrm{kg}$ IV, which produced a $43 \%$ reduction $>$ day 100 (Table 5 , CD19 MFI day $43-100$ and day $>100, P=0.04$ and $P<0.01$, respectively). However, interpretation of these results is difficult because the CD19 MFI values at baseline were statistically significantly different between the blisibimod- and placebo-treated groups (Table 5; CD19 on B cells MFI, pre-dose, $P<0.01)$. The variability in this dataset may be due to inconsistencies in the laboratory methods that were used; however, as the coefficient of reliability from our validation exercises all exceeded 0.8 , it is more likely attributable to biologic variability in our subject pool. Nonetheless, CD19 MFI was increased during administration of blisibimod, raising the possibility that blisibimod promoted a reduction in B cell activation that reversed the down-modulation of CD19 from the B cell surface in SLE patients [35]. Reduction of CD38 was also seen in blisibimod-treated subjects, occurring as early as day 15-42 of treatment (Table 5; CD38 on B cells MFI, day $15-42, P<0.01$ ). This brought the density of this marker to within the range of healthy volunteers (362-384 vs. 295 CD38 on B cells MFI).

Other agents that reduce the number of circulating $B$ cells have been tested in SLE: the anti-CD20 monoclonal antibody rituximab, a targeted B cell depletor, has been used in the clinical setting in patients with SLE despite not being approved for use in this population [36, 37]. The anti-BAFF monoclonal antibody belimumab in two phase 3 trials in SLE demonstrated improvements in clinical measurements and biomarkers of disease activity $[22,23]$, and is approved for the treatment of SLE in the United States. The BAFF- and a proliferation-inducing ligand (APRIL)-neutralizing atacicept also reduces B cell counts in patients with SLE, underscoring the versatility of options in modulating this pathway $[29,38]$. The success of belimumab and the absence of efficacy above standard of care from the rituximab clinical trials may be multifactorial and may dependent on trial design, but these results could suggest that efficacy in treating SLE may not solely be a function of reductions in B cell numbers. Yet, the positive results seen with belimumab confirm the possibility of therapeutic potential of BAFF antagonists in SLE.

A key question is whether agents that antagonize both cell-bound and circulating BAFF (e.g., blisibimod or 
Table 5 Lymphocyte counts and cell surface marker mean fluorescence intensity in phase $1 \mathrm{~b}$ subjects with systemic lupus erythematosus (SLE) treated with blisibimod or placebo compared with previously established reference ranges in healthy subjects $(H S)^{\mathrm{b}}[27]$

\begin{tabular}{|c|c|c|c|c|c|c|c|c|c|}
\hline \multirow[b]{2}{*}{ Assay } & \multicolumn{3}{|c|}{ Reference range $^{a}$} & \multirow[b]{2}{*}{ Placebo } & \multicolumn{4}{|c|}{ Blisbimod $(\mathrm{mg} / \mathrm{kg})^{\mathrm{a}}$} & \multirow[b]{2}{*}{$P$ value ${ }^{d}$} \\
\hline & $\overline{\mathrm{HS}}$ & $S L E^{b}$ & $\operatorname{CoR}^{c}$ & & $0.3 \mathrm{SC}$ & $1.0 \mathrm{SC}$ & $3.0 \mathrm{SC}$ & $6.0 \mathrm{IV}$ & \\
\hline Lymphocytes $\left(\mathrm{mm}^{3}\right)$ & $1915(84)$ & $1553(129)^{\mathrm{e}}$ & ND & & & & & & \\
\hline Pre-dose $^{f}$ & & & & $1331(700)$ & $1653(965)$ & $1244(458)$ & $1677(620)$ & $1513(707)$ & 0.47 \\
\hline Day $15-42$ & & & & $1420(61)$ & $1632(60)$ & $1439(59)$ & $1408(62)$ & $1580(59)$ & 0.97 \\
\hline Day 43-100 & & & & $1396(74)$ & $1390(78)$ & $1373(72)$ & $1357(78)$ & $1458(74)$ & 0.73 \\
\hline > Day 100 & & & & $1432(70)$ & $1422(71)$ & $1286(68)$ & $1298(73)$ & $1305(70)$ & 0.10 \\
\hline T cells $\left(\mathrm{mm}^{3}\right)$ & $1544(74)$ & $1278(109)$ & 0.83 & & & & & & \\
\hline Pre-dose ${ }^{f}$ & & & & $1112(628)$ & $1275(757)$ & $965(320)$ & $1356(547)$ & $1141(547)$ & 0.51 \\
\hline Day $15-42$ & & & & $1086(67)$ & $1242(67)$ & $1150(65)$ & $1130(72)$ & $1247(65)$ & 0.52 \\
\hline Day 43-100 & & & & $1086(69)$ & $1151(73)$ & $1121(67)$ & $1061(73)$ & $1232(69)$ & 0.95 \\
\hline > Day 100 & & & & $1151(55)$ & $1205(55)$ & $1068(53)$ & $1094(57)$ & $1139(55)$ & 0.29 \\
\hline NK cells $\left(\mathrm{mm}^{3}\right)$ & $161(18)$ & $119(14)$ & 0.80 & & & & & & \\
\hline Pre-dose $e^{e}$ & & & & $75(67)$ & $87(61)$ & $120(112)$ & $103(59)$ & $124(71)$ & 0.46 \\
\hline Day $15-42$ & & & & $98(12)$ & $105(12)$ & $88(12)$ & $100(13)$ & $142(12)$ & 0.78 \\
\hline Day 43-100 & & & & $116(12)$ & $112(13)$ & $99(12)$ & $119(13)$ & $112(12)$ & 0.67 \\
\hline > Day 100 & & & & $108(12)$ & $106(12)$ & $102(11)$ & $112(12)$ & $115(12)$ & 0.92 \\
\hline $\mathrm{CD} 19^{+} \mathrm{CD} 20^{+}\left(\mathrm{mm}^{3}\right)$ & $178(17)$ & $136(15)$ & 0.87 & & & & & & \\
\hline Pre-dose ${ }^{f}$ & & & & $112(68)$ & $194(147)$ & $140(160)$ & $169(172)$ & $165(155)$ & 0.70 \\
\hline Day $15-42$ & & & & $140(21)$ & $213(21)$ & $150(20)$ & $146(22)$ & $194(20)$ & 0.76 \\
\hline Day 43-100 & & & & $126(17)$ & $132(18)$ & $98(17)$ & $96(18)$ & $115(17)$ & 0.17 \\
\hline > Day 100 & & & & $111(15)$ & $117(15)$ & $70(14)$ & $60(15)$ & $66(15)$ & 0.01 \\
\hline $\operatorname{lgD}^{+} \mathrm{CD} 27^{+}$(naïve, $\mathrm{mm}^{3}$ ) & $123(15)$ & $101(14)$ & 0.88 & & & & & & \\
\hline Pre-dose ${ }^{f}$ & & & & $73(47)$ & $138(141)$ & $110(150)$ & $131(154)$ & $91(88)$ & 0.70 \\
\hline Day $15-42$ & & & & $97(14)$ & $134(15)$ & $91(14)$ & $84(15)$ & $154(14)$ & 0.60 \\
\hline Day 43-100 & & & & $89(13)$ & $82(14)$ & $53(13)$ & $32(14)$ & $69(13)$ & $<0.01$ \\
\hline > Day 100 & & & & $75(12)$ & $82(13)$ & $49(11)$ & $41(13)$ & $31(13)$ & 0.06 \\
\hline $\operatorname{lgD}^{+} \mathrm{CD}_{27}{ }^{+}$(memory, $\mathrm{mm}^{3}$ ) & $18.9(2.0)$ & $12.0(2.2)^{\mathrm{e}}$ & 0.80 & & & & & & \\
\hline Pre-dose ${ }^{f}$ & & & & $10(13)$ & $13(11)$ & $7(7)$ & $9(9)$ & $6(5)$ & 0.44 \\
\hline Day $15-42$ & & & & $9(3)$ & $23(3)$ & $14(3)$ & $14(3)$ & $23(3)$ & 0.09 \\
\hline Day 43-100 & & & & $8(3)$ & $14(4)$ & $14(3)$ & $11(4)$ & $25(3)$ & 0.31 \\
\hline > Day 100 & & & & $7(2)$ & $7(2)$ & $7(2)$ & $5(2)$ & $7(2)$ & 0.67 \\
\hline $\operatorname{lgD}^{-} \mathrm{CD} 27^{+}$(memory, mm³) & $24.5(2.5)$ & $14.1(2.2)^{9}$ & 0.92 & & & & & & \\
\hline Pre-dose ${ }^{f}$ & & & & $17(17)$ & $20(11)$ & $15(11)$ & $11(7)$ & $14(10)$ & 0.40 \\
\hline Day $15-42$ & & & & $15(4)$ & $37(4)$ & $24(3)$ & $28(4)$ & $32(4)$ & 0.02 \\
\hline Day 43-100 & & & & $14(4)$ & $23(4)$ & $19(4)$ & $21(4)$ & $34(4)$ & 0.22 \\
\hline > Day 100 & & & & $11(3)$ & $16(3)$ & $10(3)$ & $10(3)$ & $12(3)$ & 0.73 \\
\hline CD19 (MFI) & $63.0(1.7)$ & $44.6(2.7)^{9}$ & ND & & & & & & \\
\hline Pre-dose ${ }^{f}$ & & & & $70(37)$ & $44(11)$ & $68(22)$ & $57(9)$ & $76(17)$ & $<0.01$ \\
\hline Day $15-42$ & & & & $69(5)$ & $68(5)$ & $75(4)$ & $76(5)$ & $74(5)$ & 0.19 \\
\hline Day 43-100 & & & & $65(7)$ & $73(8)$ & $83(6)$ & $81(7)$ & $80(7)$ & 0.04 \\
\hline > Day 100 & & & & $66(5)$ & $68(5)$ & $81(4)$ & $82(5)$ & $43(5)$ & $<0.01$ \\
\hline
\end{tabular}


Table 5 Lymphocyte counts and cell surface marker mean fluorescence intensity in phase 1b subjects with systemic lupus erythematosus (SLE) treated with blisibimod or placebo compared with previously established reference ranges in healthy subjects $(\mathrm{HS})^{\mathrm{b}}[27]$ (Continued)

\begin{tabular}{|c|c|c|c|c|c|c|c|c|c|}
\hline CD38 (on B cells; MFI) & 295 (18) & $486(52)^{9}$ & ND & & & & & & \\
\hline Pre-dose ${ }^{f}$ & & & & $578(477)$ & $413(175)$ & $424(374)$ & 498 (197) & $537(292)$ & 0.68 \\
\hline Day $15-42$ & & & & $608(67)$ & $362(67)$ & $384(64)$ & $363(71)$ & $352(65)$ & $<0.01$ \\
\hline Day 43-100 & & & & $625(96)$ & $386(101)$ & $607(92)$ & $397(100)$ & $463(96)$ & 0.30 \\
\hline > Day 100 & & & & 477 (104) & $421(104)$ & 879 (99) & 654 (106) & 439 (104) & 0.02 \\
\hline
\end{tabular}

Abbreviations: CoR coefficient of reliability, IV intravenous, MFI median fluorescence intensity, ND not determined, NK natural killer, SC subcutaneous, SD standard deviation, SE standard error, SLE systemic lupus erythematosus

aTable values are mean (SE) for reference ranges, mean (SD) for pre-dose values and least squares mean (SE) for post-dose study periods

${ }^{\mathrm{b}}$ Reference range $P$ values compare values from patients with mild-to-moderate SLE with those of HS

${ }^{C} \mathrm{C} O \mathrm{R}$ was calculated by dividing the inter-subject variability by the total variability (inter-subject + intra-subject variability). This provides a reference to assess the reliability of a measure in detecting changes within a subject over time. A higher CoR indicates a measure that will be more reliable in detecting treatment effects over time since the within (intra-) subject variability is low in repeat measures testing

${ }^{\mathrm{d}}$ Blisibimod $1.0 \mathrm{mg} / \mathrm{kg}$ and $3.0 \mathrm{mg} / \mathrm{kg}$ dose groups were pooled and compared to placebo using an F-test to generate descriptive $P$ values

${ }^{\mathrm{e}} P$ value from 0.01 to $<0.05$

${ }^{f}$ Pre-dose is defined as the mean value of day 1 and the immediately preceding screen

${ }^{\mathrm{g}} P$ value $<0.01$

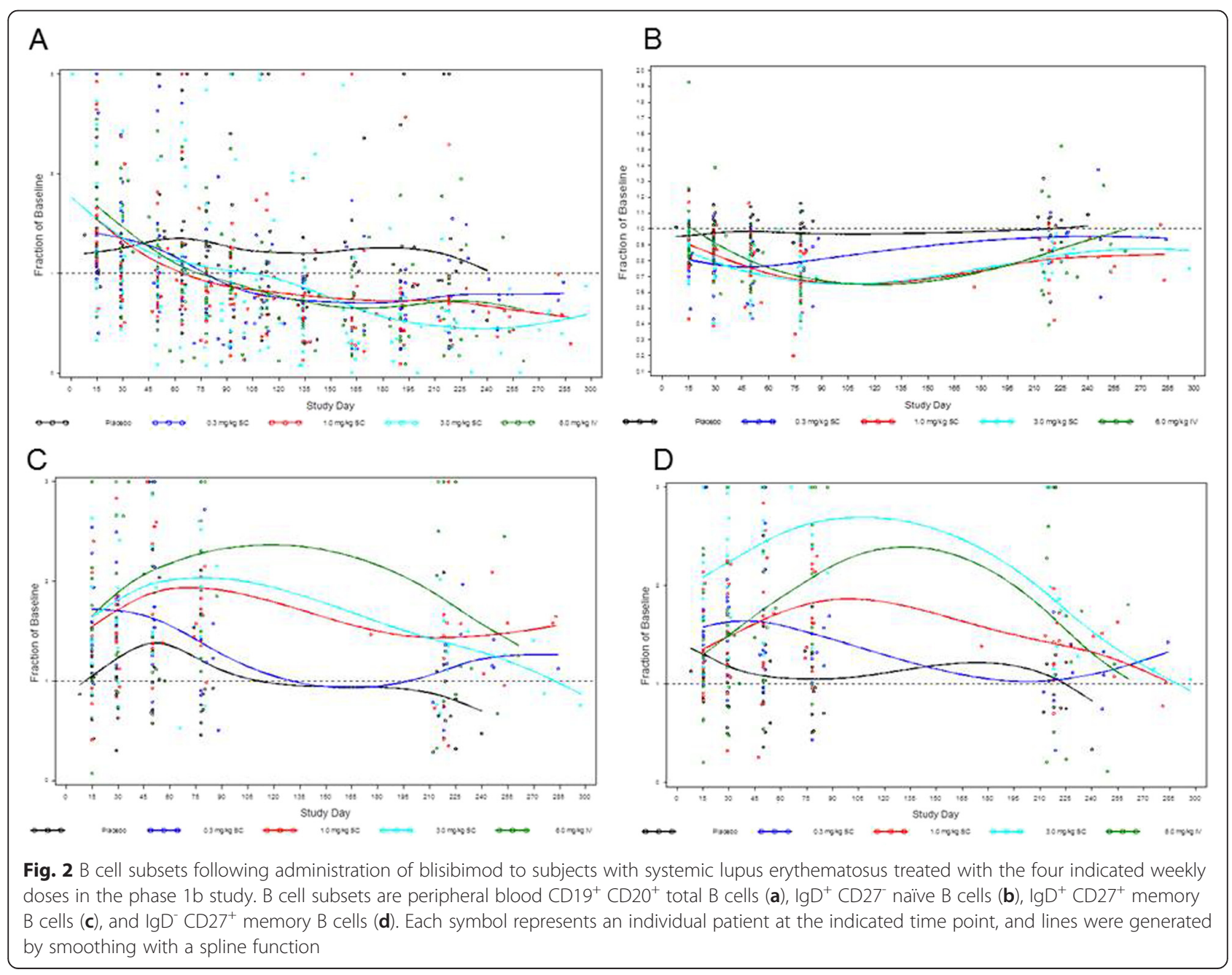


Table 6 Adverse events (AE) occurring in $\geq 5 \%$ of patients with systemic lupus erythematosus treated with blisibimod in the phase la study

\begin{tabular}{|c|c|c|c|c|c|c|c|c|c|}
\hline \multirow[b]{3}{*}{ n (\%) } & \multirow{3}{*}{$\begin{array}{l}\text { Placebo } \\
(n=14)\end{array}$} & \multicolumn{8}{|l|}{ Blisibimod } \\
\hline & & \multicolumn{4}{|l|}{$\mathrm{mg} / \mathrm{kg} \mathrm{SC}$} & \multicolumn{3}{|l|}{$\mathrm{mg} / \mathrm{kg} \mathrm{IV}$} & \multirow{2}{*}{$\begin{array}{l}\text { All } \\
(\mathrm{N}=40)\end{array}$} \\
\hline & & $0.1(n=6)$ & $0.3(n=6)$ & $1.0(n=9)$ & $3.0(n=6)$ & $1.0(n=6)$ & $3.0(n=1)$ & $6.0(n=6)$ & \\
\hline Patients reporting an $\mathrm{AE}$ & $11(79)$ & $5(83)$ & $3(50)$ & $4(44)$ & $5(83)$ & $5(83)$ & $1(100)$ & $5(83)$ & $28(70)$ \\
\hline Nausea & $4(29)$ & $2(33)$ & $0(0)$ & $2(22)$ & $2(33)$ & $0(0)$ & $0(0)$ & $0(0)$ & $6(15)$ \\
\hline Headache & $3(21)$ & $1(17)$ & $0(0)$ & $1(11)$ & $1(17)$ & $0(0)$ & $0(0)$ & $1(17)$ & $4(10)$ \\
\hline Upper respiratory tract infection & $3(21)$ & $0(0)$ & $0(0)$ & $1(11)$ & $0(0)$ & $1(17)$ & $1(100)$ & $1(17)$ & $4(10)$ \\
\hline Diarrhea & $1(17)$ & $0(0)$ & $0(0)$ & $1(11)$ & $1(17)$ & $0(0)$ & $0(0)$ & $1(17)$ & $3(8)$ \\
\hline Bronchitis & $0(0)$ & $0(0)$ & $0(0)$ & $0(0)$ & $0(0)$ & $0(0)$ & $1(100)$ & $1(17)$ & $2(5)$ \\
\hline Dizziness & $4(29)$ & $0(0)$ & $0(0)$ & $1(11)$ & $1(17)$ & $0(0)$ & $0(0)$ & $0(0)$ & $2(5)$ \\
\hline Injection site prutitus & $1(7)$ & $2(33)$ & $0(0)$ & $0(0)$ & $0(0)$ & $0(0)$ & $0(0)$ & $0(0)$ & $2(5)$ \\
\hline Pain in extremity & $1(7)$ & $0(0)$ & $0(0)$ & $0(0)$ & $1(17)$ & $0(0)$ & $0(0)$ & $1(17)$ & $2(5)$ \\
\hline Pharyngolaryngeal pain & $0(0)$ & $0(0)$ & $0(0)$ & $0(0)$ & $0(0)$ & $2(33)$ & $0(0)$ & $0(0)$ & $2(5)$ \\
\hline Shoulder pain & $0(0)$ & $2(33)$ & $0(0)$ & $0(0)$ & $0(0)$ & $0(0)$ & $0(0)$ & $0(0)$ & $2(5)$ \\
\hline Vomiting & $1(7)$ & $0(0)$ & $0(0)$ & $1(11)$ & $1(17)$ & $0(0)$ & $0(0)$ & $0(0)$ & $2(5)$ \\
\hline
\end{tabular}

Abbreviations: IV intravenous, SC subcutaneous

tabulumab) will have a different spectrum of efficacy than those that bind only to soluble BAFF (e.g., belimumab) [39]. In a 24-week, phase $2 \mathrm{~b}$, placebocontrolled study of blisibimod in 547 patients with SLE, treatment with blisibimod decreased B cell counts, reduced disease activity, and prolonged time to first severe disease flare [40]. The reductions in B cell counts in this study were comparable with those reported with belimumab [23]. Likewise, a preliminary report confirmed some B cell reductions in phase 3 trials of the soluble and bound BAFF antagonist tabulumab [41].

Little is known about the nature and purpose of membrane-bound BAFF. The phenotype of genetically engineered mice that express membrane-bound BAFF and almost no soluble BAFF is similar to that of BAFFdeficient mice, with marked reductions in B cells, serum immunoglobulin (Ig) levels, and antigen-specific Ig responses [42]. Based on this, patients with SLE in whom

Table 7 Adverse events (AE) occurring in $\geq 10 \%$ of patients with systemic lupus erythematosus treated with blisibimod in the phase $1 \mathrm{~b}$ study

\begin{tabular}{|c|c|c|c|c|c|c|}
\hline \multirow[b]{3}{*}{ n (\%) } & \multirow{3}{*}{$\begin{array}{l}\text { Placebo } \\
(\mathrm{n}=13)\end{array}$} & \multicolumn{5}{|l|}{ Blisibimod } \\
\hline & & \multicolumn{3}{|l|}{$\mathrm{mg} / \mathrm{kg} \mathrm{SC}$} & \multirow{2}{*}{$\begin{array}{l}6.0 \mathrm{mg} / \mathrm{kg} \mathrm{IV} \\
(\mathrm{n}=12)\end{array}$} & \multirow{2}{*}{$\begin{array}{l}\text { All } \\
(N=49)\end{array}$} \\
\hline & & $0.3(n=12)$ & $1.0(n=13)$ & $3.0(n=12)$ & & \\
\hline Patients reporting an $\mathrm{AE}$ & $12(92)$ & $12(100)$ & $13(100)$ & $11(92)$ & $11(92)$ & $47(96)$ \\
\hline Nasopharyngitis & $1(8)$ & $2(17)$ & $5(38)$ & $2(17)$ & $2(17)$ & $11(22)$ \\
\hline Headache & $0(0)$ & $0(0)$ & $2(15)$ & $2(17)$ & $2(17)$ & $11(22)$ \\
\hline Injection site erythema & $0(0)$ & $0(0)$ & $2(31)$ & $3(25)$ & $0(0)$ & $7(17)$ \\
\hline Nausea & $1(8)$ & $1(8)$ & $1(8)$ & $3(25)$ & $2(17)$ & $7(14)$ \\
\hline Injection site prutitus & $0(0)$ & $0(0)$ & $3(23)$ & $3(25)$ & $0(0)$ & $6(12)$ \\
\hline Upper respiratory tract infection & $0(0)$ & $3(25)$ & $2(15)$ & $0(0)$ & $1(8)$ & $6(12)$ \\
\hline Urinary tract infection & $2(15)$ & $0(0)$ & $2(15)$ & $3(25)$ & $1(8)$ & $6(12)$ \\
\hline Arthralgia & $2(15)$ & $1(8)$ & $1(8)$ & $2(17)$ & $1(8)$ & $5(10)$ \\
\hline Back pain & $0(0)$ & $1(8)$ & $1(8)$ & $2(17)$ & $1(8)$ & $5(10)$ \\
\hline Diarrhea & $3(23)$ & $1(8)$ & $1(8)$ & $3(25)$ & $0(0)$ & $5(10)$ \\
\hline Gastroesophogeal reflux disease & $0(0)$ & $1(8)$ & $2(15)$ & $2(17)$ & $0(0)$ & $5(10)$ \\
\hline Systemic lupus & $2(15)$ & $2(17)$ & $1(8)$ & $1(8)$ & $1(8)$ & $5(10)$ \\
\hline
\end{tabular}

Abbreviations: IV intravenous, SC subcutaneous 
both membrane-expressed and soluble BAFF have been neutralized may have a clinical response no different from that of patients in whom only soluble BAFF has been neutralized (e.g., belimumab). However, since expression of membrane-bound BAFF in the genetically engineered mice was low [42], there may not have been sufficient membrane-expressed BAFF to clarify its function.

In addition to effects on B cells, BAFF can costimulate in vitro proliferation of and cytokine production by $\mathrm{T}$ cells $[43,44]$, and in mice it can skew in vivo inflammatory responses toward a $\mathrm{T}$ helper (Th) 1 cell profile and away from a Th2 cell profile in a B cellindependent manner [45]. Moreover, BAFF promotes generation of Th17 cells at least in part through direct effects on $\mathrm{T}$ cells [46]. Whether membrane-expressed BAFF might contribute to these BAFF-driven effects on $T$ cells is unknown.

These were a priori first-in-human studies, and the reason for the large portion of subjects testing positive for neutralizing antibodies is unknown. Ten and $4 \%$ of subjects in the phase $1 \mathrm{a}$ and $1 \mathrm{~b}$ studies, respectively, tested positive for antibodies prior to dosing. As previous use of an investigational product was an exclusion criteria (belimumab was an investigational product at the time of the studies), prior exposure to belimumab would not explain these findings. Of the three subjects who had neutralizing antibodies during the studies, the nature and frequency of adverse events did not differ from the group as a whole, and all three subjects were negative for neutralizing antibodies at the end of the study. Given that a large portion of the subjects in these studies were positive for antibodies at any time, we believe this may be a characteristic of this population or perhaps a limitation of the assay, which may require further development [40].

A limitation of these studies is that this population had mild stable or inactive disease (mean SLE Disease Activity Index score of approximately 3 ) and baseline immune-phenotypic profiles that were more similar to those of the healthy population than patients with SLE [27]. This may have made it difficult to appreciate significant immunologic changes seen in these studies. Moreover, many patients were being treated with immunosuppressives and steroids, which could have impacted baseline B cell levels. There were also some baseline differences between the dosing groups in some B cell measurements. Although this most likely reflects the heterogeneity of the population, this may have muted or amplified treatment responses in these small treatment groups.

\section{Conclusions}

Single and multiple doses of blisibimod produced approximate dose-proportional pharmacokinetics across the dosing range of $1.0-6.0 \mathrm{mg} / \mathrm{kg}$, and significant changes in B cell subpopulations and B cell surface molecule density. Blisibimod was well tolerated, with a safety and tolerability profile similar to that of placebo. These findings support the potential of BAFF antagonists such as blisibimod in the treatment of SLE and other B cellmediated diseases. Larger clinical trials of blisibimod in SLE should be advanced to assess its efficacy in SLE and other autoimmune diseases in which B cells play an important role in pathogenesis.

\section{Abbreviations}

AE: adverse event; APRIL: a proliferation-inducing ligand; AR: accumulation ratio; $A \cup C_{0-t}$ : area under the plasma-concentration curve from time of treatment to the last measureable concentration; BAFF: B cell-activating factor; BLyS: B lymphocyte stimulator; $C_{0}$ : estimated initial concentration after IV bolus dosing; $\mathrm{CL}$ : clearance; CL/F: apparent clearance after SC dosing; $C_{\text {max: }}$ maximum observed serum concentration; ECG: electrocardiogram: $I_{50}$ : half-maximal inhibitory concentration; Ig: immunoglobulin; IRB: Institutional Review Board; IV: intravenous; MedDRA: Medical Dictionary for Regulatory Activities; MFI: median fluorescence intensity; NIH CTCAE: National Institute of Health Common Toxicity Criteria for Adverse Events; SAE: serious AE; SC: subcutaneous; SLE: systemic lupus erythematosus; $\mathrm{t}_{1 / 2, z}$ : half-life; Th: $T$ helper cell; $t_{\max }$ : time to $C_{\text {max }}$.

\section{Competing interests}

WS has been a member of scientific advisory boards for Eli Lilly, a consultant for Novartis and Celgene, received preclinical grant support from Xencor and clinical trial support from Pfizer and GlaxoSmithKline; he has no other conflicts of interest to declare. JTM has received consulting fees and grant support from Human Genome Sciences and GlaxoSmithKline. RJL has served as a consultant to Genentech, Biogen Idec, and Roche; she has no other conflicts of interest to declare. JB has received consulting fees from GlaxoSmithKline and Human Genome Sciences, Inc; she has no other conflicts of interest to declare. MHW has received consulting fees and research support from Centocor; he has no other conflicts of interest to declare. EMG was a consultant to EMD Serono, Inc, GlaxoSmithKline, and Human Genome Sciences; she has no other conflicts of interest to declare. BC, AK, TCC, ER, JF, and WT are and DH, KRK, SSB, and DJZ were employees of Amgen, Inc; they have no other conflicts of interest to declare. This study was funded by Amgen, Inc., and blisibimod is now licensed to Anthera Pharmaceuticals, Inc.

\section{Authors' contributions}

WS, BC, DH, AK, KRK, TCC, ER, JF, SSB, and DJZ designed the studies, collected and interpreted the data, drafted and revised the manuscript critically for important intellectual content. JTM, RJL, JB, DJW, MHW, EMG, and WT designed the studies, collected and interpreted the data, and revised the manuscript critically for important intellectual content. All authors approved the final version to be published.

\section{Acknowledgments}

We thank the SLE patients and the investigators for their willingness to participate in these clinical trials, as well as the individual ethical review bodies at each institution: the University of North Carolina at Chapel Hill Chairman of the Committee on the Protection of the Rights of Human Subjects; the Oklahoma Research Foundation; the SUNY Downstate Medical Center Institutional Review Board (IRB); the IRB Associates of Clinical Trial Development at New York University School of Medicine; the IRB of the Health Research Association and University of Southern California School of Medicine; Danbury Hospital IRB; the Cedars-Sinai Medical Center IRB; the Western IRB; the Human Protection Program; the University of Pittsburgh IRB; and the Biomedical Research Alliance. Editorial assistance was provided by Janice Carlson at Amgen, Inc. These studies were supported by Amgen, Inc., Thousand Oaks, CA, USA. Blisibimod is licensed to Anthera Pharmaceuticals, Inc., Hayward, CA, USA, for further development. 


\section{Author details}

${ }^{1}$ Los Angeles County and University of Southern California Medical Center and University of Southern California Keck School of Medicine, 1975 Zona Ave., Los Angeles, CA 90033, USA. ${ }^{2}$ Oklahoma Medical Research Foundation, 825 NE 13th St., Oklahoma City, OK 73104, USA. ${ }^{3}$ University of Rochester, 252 Elmwood Ave., Rochester, NY 14627, USA. ${ }^{4}$ Hospital for Joint Disease, $301 \mathrm{E}$ 17th St., New York, NY 10003, USA. ${ }^{5}$ Cedars-Sinai Medical Center, 8700 Beverly Blvd., Los Angeles, CA 90048, USA. ${ }^{5}$ SUNY Downstate Medical Center, 450 Clarkson Ave., Brooklyn, NY 11203, USA. ${ }^{7}$ Amgen Inc., 1 Amgen Center Dr., Thousand Oaks, CA 91320, USA. ${ }^{8}$ Formerly of Amgen, Inc., 1 Amgen Center Dr., Thousand Oaks, CA 91320, USA. ${ }^{9}$ Division of Rheumatology, Los Angeles County + University of Southern California Medical Center and Keck School of Medicine of the University of Southern California, 2011 Zonal Ave., Los Angeles, CA 90033, USA.

\section{Received: 19 March 2015 Accepted: 5 August 2015 Published online: 20 August 2015}

\section{References}

1. Thompson J, Schneider P, Kalled S, Wang L, Lefevre E, Cachero T, et al. BAFF binds to the tumor necrosis factor receptor-like molecule B cell maturation antigen and is important for maintaining the peripheral B cell population. J Exp Med. 2000;192:129-35.

2. Do R, Hatada E, Lee $H$, Tourigny M, Hilbert D, Chen-Kiang S. Attenuation of apoptosis underlies B lymphocyte stimulator enhancement of humoral immune response. J Exp Med. 2000;192:953-64.

3. Batten M, Groom J, Cachero T, Qian F, Schneider P, Tschopp J, et al. BAFF mediates survival of peripheral immature B lymphocytes. J Exp Med. 2000;192:1453-66.

4. Gross J, Dillon S, Mudri S, Johnston J, Littau A, Roque R, et al. TACl-lg neutralizes molecules critical for B cell development and autoimmune disease impaired B cell maturation in mice lacking BLyS. Immunity. 2001;15:289-302.

5. Schiemann B, Gommerman J, Vora K, Cachero T, Shulga-Morskaya S, Dobles M, et al. An essential role for BAFF in the normal development of B cells through a BCMA-independent pathway. Science. 2001;293:2111-4.

6. Mackay F, Woodcock S, Lawton P, Ambrose C, Baetscher M, Schneider P, et al. Mice transgenic for BAFF develop lymphocytic disorders along with autoimmune manifestations. J Exp Med. 1999;190:1697-710.

7. Khare S, Sarosi I, Xia X, McCabe S, Minder K, Solovyev I, et al. Severe B cell hyperplasia and autoimmune disease in TALL-1 transgenic mice. PNAS 2000;97:3370-5.

8. Gross J, Johnston J, Mudri S, Enselman R, Dillon S, Madden K, et al. TACl and BCMA are receptors for a TNF homologue implicated in B-cell autoimmune disease. Nature. 2000:404:995-9.

9. Stohl W, Xu D, Kim K, Koss M, Jorgensen T, Deocharan B, et al. BAFF overexpression and accelerated glomerular disease in mice with incomplete genetic predisposition to systemic lupus erythematosus. Arthritis Rheum. 2005:52:2080-91

10. Groom J, Fletcher C, Walters S, Grey S, Watt S, Sweet M, et al. BAFF and MyD88 signals promote a lupus-like disease independent of T cells. J Exp Med. 2007:204:1959-71.

11. Kayagaki N, Yan M, Seshasayee D, Wang H, Lee W, French D, et al. BAFF/ BLyS receptor 3 binds the B cell survival factor BAFF ligand through a discrete surface loop and promotes processing of NF-kappaB2. Immunity. 2002:17:515-24.

12. Ramanujam M, Wang $X$, Huang W, Liu Z, Schiffer $L$, Tao $H$, et al. Similarities and differences between selective and nonselective BAFF blockade in murine SLE. J Clin Invest. 2006;116:724-34.

13. Jacob C, Pricop L, Putterman C, Koss M, Liu Y, Kollaros M, et al. Paucity of clinical disease despite serological autoimmunity and kidney pathology in lupus-prone New Zealand mixed 2328 mice deficient in BAFF. J Immunol. 2006;177:2671-80.

14. Zhang J, Roschke V, Baker K, Wang Z, Alarcón G, Fessler B, et al. Cutting edge: a role for $B$ lymphocyte stimulator in systemic lupus erythematosus. J Immunol. 2001;166:6-10.

15. Cheema G, Roschke V, Hilbert D, Stohl W. Elevated serum B Iymphocyte stimulator levels in patients with systemic immune-based rheumatic diseases. Arthritis Rheum. 2001:44:1313-9.

16. Stohl W, Metyas S, Tan S, Cheema G, Oamar B, Xu D, et al. B lymphocyte stimulator overexpression in patients with systemic lupus erythematosus: longitudinal observations. Arthritis Rheum. 2003;48:3475-86.
17. Petri M, Stohl W, Chatham W, McCune W, Chevrier M, Ryel J, et al. Association of plasma B lymphocyte stimulator levels and disease activity in systemic lupus erythematosus. Arthritis Rheum. 2008;58:2453-9.

18. Collins C, Gavin A, Migone T, Hilbert D, Nemazee D, Stohl W. B lymphocyte stimulator (BLyS) isoforms in systemic lupus erythematosus: disease activity correlates better with blood leukocyte BLyS mRNA levels than with plasma BLyS protein levels. Arthritis Res Ther. 2006;8:R6.

19. Becker-Merok A, Nikolaisen C, Nossent H. B-lymphocyte activating factor in systemic lupus erythematosus and rheumatoid arthritis in relation to autoantibody levels, disease measures and time. Lupus. 2006;15:570-6.

20. Ju S, Zhang D, Wang Y, Ni H, Kong X, Zhong R. Correlation of the expression levels of BLyS and its receptors mRNA in patients with systemic lupus erythematosus. Clin Biochem. 2006;39:1131-7.

21. Hong S, Reiff A, Yang H, Migone T, Ward C, Marzan K, et al. B lymphocyte stimulator expression in pediatric systemic lupus erythematosus and juvenile idiopathic arthritis patients. Arthritis Rheum. 2009;60:3400-9

22. Navarra S, Guzmán R, Gallacher A, Hall S, Levy R, Jimenez R, et al. Efficacy and safety of belimumab in patients with active systemic lupus erythematosus: a randomised, placebo-controlled, phase 3 trial. Lancet. 2011;377:721-31.

23. Furie $\mathrm{R}$, Petri $\mathrm{M}$, Zamani $\mathrm{O}$, Cervera $\mathrm{R}$, Wallace $\mathrm{D}$, Tegzová $\mathrm{D}$, et al. A phase III, randomized, placebo-controlled study of belimumab, a monoclonal antibody that inhibits B lymphocyte stimulator, in patients with systemic lupus erythematosus. Arthritis Rheum. 2011;63:3918-30.

24. Hsu H, Khare S, Lee F, Miner K, Hu Y, Stolina M, et al. A novel modality of BAFF-specific inhibitor AMG623 peptibody reduces B-cell number and improves outcomes in murine models of autoimmune disease. Clin Exp Rheumatol. 2012;30:197-201.

25. Tan E, Cohen A, Fries J, Masi A, McShane D, Rothfield N, et al. The 1982 revised criteria for the classification of systemic lupus erythematosus. Arthritis Rheum. 1982;25:1271-7.

26. Hochberg M. Updating the American College of Rheumatology revised criteria for the classification of systemic erythematosus lupus. Arthritis Rheum. 1997:40:1725-34

27. Belouski S, Wallace D, Weisman M, Ishimori M, Hendricks L, Zack D, et al. Sample stability and variability of B-cell subsets in blood from healthy subjects and patients with systemic lupus erythematosus. Cytometry B Clin Cytom. 2010;78:49-58.

28. Reinsch C. Smoothing by spline functions. Numer Math. 1967;10:177-83.

29. Dall'Era M, Chakravarty E, Wallace D, Genovese M, Weisman M, Kavanaugh A, et al. Reduced B lymphocyte and immunoglobulin levels after atacicept treatment in patients with systemic lupus erythematosus: results of a multicenter, phase lb, double-blind, placebo-controlled, dose-escalating trial. Arthritis Rheum. 2007:56:4142-50.

30. Tak P, Thurlings R, Rossier C, Nestorov I, Dimic A, Mircetic V, et al. Atacicept in patients with rheumatoid arthritis: results of a multicenter, phase $\mathrm{lb}$, double-blind, placebo-controlled, dose-escalating, single- and repeateddose study. Arthritis Rheum. 2008;58:61-72.

31. Wallace D, Stohl W, Furie R, Lisse J, McKay J, Merrill J, et al. A phase II, randomized, double-blind, placebo-controlled, dose-ranging study of belimumab in patients with active systemic lupus erythematosus. Arthritis Rheum. 2009;61:1168-78.

32. Stohl W, Hiepe F, Latinis $K$, Thomas $M$, Scheinberg $M$, Clarke $A$, et al. Belimumab reduces autoantibodies, normalizes low complement levels, and reduces select $B$ cell populations in patients with systemic lupus erythematosus. Arthritis Rheum. 2012;64:2328-37.

33. Looney R, Anolik J, Campbell D, Felgar R, Young F, Arend L, et al. B cell depletion as a novel treatment for systemic lupus erythematosus: a phase $1 / \|$ dose-escalation trial of rituximab. Arthritis Rheum. 2004;50:2580-9.

34. Sato S, Hasegawa M, Fujimoto M, Tedder TF, Takehara K. Quantitative genetic variation in CD19 expression correlates with autoimmunity. J Immunol. 2000;165:6635-43.

35. Korganow AS, Knapp AM, Nehme-Schuster H, Soulas-Sprauel P, Poindron V Pasquali $J$, et al. Peripheral B cell abnormalities in patients with systemic lupus erythematosus in quiescent phase: decreased memory B cells and membrane CD19 expression. J Autoimmun. 2010:34:426-3.

36. Merrill JT, Neuwelt CM, Wallace DJ, Shanahan JC, Latinis KM, Oates JC, et al. Efficacy and safety of rituximab in moderately-to-severely active systemic lupus erythematosus: the randomized, double-blind, phase II/III systemic lupus erythematosus evaluation of rituximab trial. Arthritis Rheum. $2008: 62: 222-33$. 
37. Rovin BH, Furie R, Latinis K, Looney RJ, Fervenza FC, Sanchez-Guerrero J, et al. Efficacy and safety of rituximab in patients with active proliferative lupus nephritis: the Lupus Nephritis Assessment with Rituximab study. Arthritis Rheum. 2012;64:1215-26.

38. Pena-Rossi C, Nasonov E, Stanislav M, Yakusevich V, Ershova O, Lomareva N, et al. An exploratory dose-escalating study investigating the safety, tolerability, pharmacokinetics and pharmacodynamics of intravenous atacicept in patients with systemic lupus erythematosus. Lupus. 2009; 18:547-55

39. Baker KP, Edwards BM, Main SH, Choi GH, Wager RE, Halpern WG, et al. Generation and characterization of LymphoStat-B, a human monoclonal antibody that antagonizes the bioactivities of B lymphocyte stimulator. Arthritis Rheum. 2003;48:3253-65.

40. Furie RA, Scheinberg MA, Leon G, Ramiterre EB, Thomas M, Martin RS, et al. A phase 2, randomised, placebo-controlled clinical trial of blisibimod, an inhibitor of B cell activating factor, in patients with moderate-to-severe systemic lupus erythematosus, the PEARL-SC study. Ann Rheum Dis 2014. doi: 10.1136/annrheumdis-2013-205144. Epub ahead of print.

41. Isenberg DA, Urowitz MB, Merrill JT, Hoffman RW, Linnik MD, Morgan-Cox M, et al. Efficacy and Safety of subcutaneous tabalumab in patients with systemic lupus erythematosus (SLE): Results from 2 phase 3, 52-week, multicenter, randomized, double-blind, placebo-controlled trials. Arthritis Rheum. 2014;66:S225.

42. Bossen C, Tardivel A, Willen L, Fletcher C, Perroud M, Beermann F, et al. Mutation of the BAFF furin cleavage site impairs B-cell homeostasis and antibody responses. Eur J Immunol. 2011;41:787-97.

43. Huard B, Schneider P, Mauri D, Tschopp J, French L. T cell costimulation by the TNF ligand BAFF. J Immunol. 2001;167:6225-31.

44. Ng L, Sutherland A, Newton R, Qian F, Cachero T, Scott M, et al. B cellactivating factor belonging to the TNF family (BAFF)-R is the principal BAFF receptor facilitating BAFF costimulation of circulating T and B cells. J Immunol. 2004; $173: 807-17$.

45. Sutherland A, Ng L, Fletcher C, Shum B, Newton R, Grey S, et al. BAFF augments certain Th1-associated inflammatory responses. J Immunol. 2005;174:5537-44.

46. Zhou X, Xia Z, Lan Q, Wang J, Su W, Han Y, et al. BAFF promotes Th17 cells and aggravates experimental autoimmune encephalomyelitis. PLoS One. 2011;6, e23629.

\section{Submit your next manuscript to BioMed Central and take full advantage of:}

- Convenient online submission

- Thorough peer review

- No space constraints or color figure charges

- Immediate publication on acceptance

- Inclusion in PubMed, CAS, Scopus and Google Scholar

- Research which is freely available for redistribution 